International Journal of Business Management and Economic Review

Vol. 4, No. 06; 2021

ISSN: 2581-4664

\title{
THE INFLUENCE OF UNDERSTANDING OF FINANCIAL MANAGEMENT APPARATUS, THE UTILIZATION OF INFORMATION TECHNOLOGY AND INTERNAL CONTROL SYSTEM ON THE ACCOUNTABILITY OF VILLAGE FUND MANAGEMENT IN ACEH SINGKIL DISTRICT, PROVINCE OF ACEH, INDONESIA
}

\author{
Mohammad Natsir, Yossi Diantimala and Muslim A. Djalil* \\ Magister of Accountancy Program, Faculty of Economics and Business Universitas Syiah Kuala, Banda Aceh, \\ Indonesia
}

http://doi.org/10.35409/IJBMER.2021.3334

\begin{abstract}
This study aims to examine the effect of understanding financial management apparatus, the utilization of information technology and internal control systems on the accountability of village fund management both simultenously and partially in Aceh Singkil District. The population of this study are all villages in Aceh Singkil which consisted of 116 villages from 11 districts. The research sample was obtained as many as 52 villages using purposive sampling method. The sampling technique used stratified random sampling. Furthermore, those who will be used as research respondents are the Village Head and Village Financial Management Technical Implementers (PTPKD) consisting of the Village Secretary, Section Head and Village Treasurer with a total of 208 respondents. Sources of data in this study using primary source of which obtained throughthe acquisition of questionnaires from respondents. While the research data collection technique was carried out by using documentation techniques, thee analytical method used is Multiple Linear Regression Analysis. The results showed that the understanding of the financial management apparatus, the utilization of information technology and the internal control system have a significant effect either simultenously and partially on the accountability of village fund management in Aceh Singkil District.
\end{abstract}

Keyword: Understanding of the Financial Management Apparatus, Utilization of Information Technology, Internal Control System, Accountability of Village Fund Management.

\section{INTRODUCTION}

The high demand of the public for state finances to be managed with the principles of good governance have an impact on the demand for maximum service to the public and credible and accurate information on state finances. Therefore, good governance in a country is an inevitable need. The government is obliged to apply good principles in running the wheels of government, including those in the field of state financial management which are embodied in the application of the principles of good governance (Mardiasmo, 2002).

Village financial management can be very sensitive in the community if it is not managed properly. Therefore, accountability for village financial management is needed. Current problems related to the management of village funds are; (1) the accountability report made by the village has not followed the standards and is prone to manipulation. As 


\section{International Journal of Business Management and Economic Review}

Vol. 4, No. 06; 2021

ISSN: 2581-4664

well as the formulated APBDesa does not fully reflect the needs of the village; (2) in the aspect of supervision, there are three potential problems faced, namely the low effectiveness of the regional inspectorate in supervising financial management in the village, the poor management of public complaint channels by all regions and the unclear scope of the evaluation of the supervision carried out by the camat. ; and (3) from the aspect of human resources, there is a potential problem, namely assistants have the potential to commit corruption by exploiting the weakness of village officials (Pramesti, 2015).

Apart from this phenomenon, cases of financial management of village funds also occur in local governments such as in Aceh Singkil District. As quoted from online media sources, several villages with problems related to the management of village funds were found, such as Kampung Baru Village, Sukamakmur Village, Kampung Selok Village and several villages in Singkil District. The findings of financial management problems are related to misappropriation of the village fund budget and non-compliance of village officials with financial management in accordance with Permendagri No. 113/2014 concerning Village Financial Management (Putra, 2017).

Based on these findings, it can be judged that the management of village funds in Aceh Singkil District is not yet fully good. This can have an impact on the low assessment of transparency and public accountability. Public accountability is the obligation of a person who is given an order to be responsible, submit and explain all of his activities and activities that are the duty of the trustee who has the right and power to ask for this accountability (Mardiasmo, 2010). In relation to the accountability of village fund management, it can be concluded as a form of the village head's obligation to be responsible for managing the village funds assigned to him in order to achieve the goals that have been set through directed responsibility (Hasniati, 2016).

Research related to the accountability of village fund management has been conducted before (Yesinia, Yuliarti and Puspitasari, 2018; Yudianto and Sugiarti, 2018; Hadiyati, 2018; Suherwan and Kamaliah, 2017; Naimah, 2017; Indrianasari, 2017; Mudarosatun, 2017; Hasniati, 2016 ; Jurniadi, Djumadi and Paranoan, 2015). Based on the results of this study, several factors can be determined that can affect the management of village funds.

First, the understanding of the financial management apparatus has an influence on the accountability of village fund management (Yesinia, Yuliarti, and Puspitasari, 2018; Indrianasari, 2017; Hasniati, 2016). The village fund management apparatus is still inadequate and inadequate in managing village funds, both from elements of the village government and village community organizations, with less optimal planning, implementation and control of activities in the management of village funds. Lack of community participation, lack of involvement of village community organizations, and lack of facilities for companion teams and supervision from the community are things that must be understood by village fund management officials (Suherwan and Kamaliah, 2017).

Second, the use of information technology has an influence on the accountability of village fund management (Sapartiningsih, Suharno and Kristianto, 2018; Yudianto and Sugiarti, 2018; Suherwan and Kamaliah, 2017). The use of information technology is required for reliable financial reporting. According to Suparman (2014:3) the use of information technology includes data processing, information processing, management 


\section{International Journal of Business Management and Economic Review}

Vol. 4, No. 06; 2021

ISSN: 2581-4664

systems, electronic work processes and the use of advances in information technology so that public services can be accessed easily and cheaply by the public. This shows that the use of information technology in the form of computers helps village officials in managing village documents as a whole. This computer is also used as a work aid in the process of preparing village government financial reports, so that village officials are able to input data more quickly than using the manual method.

Third, the internal control system has an influence on the accountability of village fund management (Yesinia, Yuliarti and Puspitasari, 2018; Yudianto and Sugiarti, 2018; Naimah, 2017). According to the Financial and Development Supervisory Agency (BPKP), APIP or Government Agency Supervisory Apparatus as a means of fostering the implementation of the Government Agency Internal Control System (SPIP) states that SPIP has an important role in overseeing the accountability of village financial management both in terms of assurance and consulting. This is in line with the mandate in Government Regulation Number 60 of 2008, which states that APIP carries out internal supervision of the implementation of duties and functions of government agencies including financial accountability and fostering the implementation of SPIP.

The reason for choosing Aceh Singkil as the object of research is based on preliminary observations that the researcher found that there are still problems and phenomena related to the accountability of village fund management. There are still many villages in Aceh Singkil involved legally due the village fund management is not good, therefore, researchers are interested to further examine the factors that affect the accountability and villages d i Singkil.

\section{LITERATURE REVIEW}

\section{Accountability of Village Fund Management}

Budiardjo (2003:78) defines accountability as "the responsibility of those who are given the mandate to govern those who give them authority". Furthermore, Widodo (2011:67) explains accountability as "a concept with respect to external standards that determine the correctness of a bureaucratic action". Accountability itself means providing information and disclosure of financial activities and performance to interested parties (Schiavo-Campo and Tomasi, 1999). In addition, accountability also means a form of obligation to account for the success or failure of the organization's mission in achieving the goals and objectives that have been previously set, through an accountability medium which is carried out periodically (Stanbury, 2003:12). According to Law Number 6 of 2014, village funds are funds sourced from the State revenue and expenditure budget allocated to villages that are transferred through the district/city regional revenue and expenditure budget and are used to finance governance, implementation, development, community development and community development.

\section{Understanding of the Financial Management Apparatus}

Village financial management is all activities that include planning, implementation, administration, reporting, and village financial accountability. The implementation of village authority based on rights of origin and village-scale local authority is funded by the Village Budget. In addition to being funded by the Village Budget, the implementation of village-scale local 


\section{International Journal of Business Management and Economic Review}

Vol. 4, No. 06; 2021

ISSN: 2581-4664

authorities can also be funded by the State Revenue and Expenditure Budget and the Regional Revenue and Expenditure Budget. The implementation of village authority assigned by the Government is funded by the State Revenue and Expenditure Budget. The State Revenue and Expenditure Budget Fund is allocated to the budget section of Ministries / Institutions and channeled through Regency/City Regional Work Units (Agus and Madya, 2015). Management carried out by the Village is all rights and obligations of the Village which can be valued in money as well as everything in the form of money and goods related to the implementation of the rights and obligations of the Village. Village finances are managed based on the principles of Transparency, Accountability, Participation and carried out in an orderly and disciplined budget. Village finances are managed within 1 fiscal year, starting from January 1 to December 31 (Sujarweni, 2015).

\section{Utilization of Information Technology}

According to Indrajit (2000) information technology is a technology related to processing data into information and the process of distributing the data or information within the boundaries of time and space. Information systems can be classified as a demand from the industrial community when the need for fast and inexpensive data processing and communication facilities. As a result, information technology is a component that cannot be separated from the office mechanism. The same thing was also expressed by Lantip and Riyanto (2011:4) that information technology is defined as knowledge in the field of computer-based information and its development is very rapid. Hamzah and Lamatenggo (2011:57) also suggest that information technology is a technology used to process data. The use of technology is related to the behavior of using the technology to complete tasks. The theory of attitudes and behavior developed by Triandis (1980) states that the use of a personal computer or PC (Personal Computer) by users who have optional knowledge in the environment is influenced by their affect on utilization. PC, workplace social norms that utilize PC, habits related to computer use, individual expected consequences (consequencies) from PC utilization and facilitating conditions in a conducive environment using PC (Wijaya, 2005: 39).

\section{Internal Control System}

Government Regulation Number 60 of 2008 concerning the Government Internal Control System defines the Internal Control System hereinafter abbreviated as SPI as: "An integral process for actions and activities carried out continuously by the leadership and all employees to provide adequate confidence in the achievement of organizational goals through effective activities. and efficiency, reliability of financial reporting, safeguarding state assets, and compliance with laws and regulations ". Therefore, the leaders are obliged to exercise control over the administration of government activities in order to achieve effective, efficient, transparent and accountable management of state finances by referring to these regulations. SPIP elements in Government Regulation Number 60 of 2008 refer to SPI elements that have been practiced in government circles in various countries . Government Regulation Number 60 of 2008 also mandates that in order to strengthen and support the effectiveness of the implementation of SPI, it is necessary to carry out internal supervision and fostering the implementation of SPIP.

\section{RESEARCH METHOD}




\section{International Journal of Business Management and Economic Review}

Vol. 4, No. 06; 2021

ISSN: 2581-4664

This research is a sample study because not all members of the population are made respondents. The population of this study were all villages in Aceh Singkil Regency which consisted of 116 villages from 11 districts. The research sample used purposive sampling method. The reason for using the purposive sampling method is because the researcher has determined special characteristics that are in accordance with the research issue, namely villages that only have problems related to the management of village funds in each district. The sampling technique used stratified random sampling. Furthermore, those who will be used as research respondents are the Village Head and Village Financial Management Technical Implementer (PTPKD) which consists of the Village Secretary, Section Head and Village Treasurer. The reason for choosing the respondent was because it was the one who was authorized and directly responsible for managing village funds. The data source in this study uses primary data, namely the acquisition of questionnaires from respondents. While the research data collection technique was carried out by using documentation techniques. The analytical method used is Multiple Linear Regression Analysis.

Operationalization of variables in this study can be described as follows;

a. Village Fund Management Accountability (Y), Village fund management accountability is the obligation to provide accountability or answer and explain the performance and actions of the village head to the Regent in the form of a report on the principle that every village financial management activity must be accountable to the village community, in accordance with statutory regulations invitation. The indicators used are based on Sapartiningsih, Suharno and Kristianto (2018) which include; APBDes management is presented in an open, fast, and precise manner, APBDes management involves all elements of the community, the presentation of the APBDes is accompanied by information from the previous period, the accountability of the APBDes is conveyed to the district government and the community. The scale used is an interval scale in the form of a 5-point Likert scale.

b. Understanding of the Financial Management Apparatus $\left(\mathrm{X}_{1}\right)$. The understanding of the financial management apparatus is the understanding by the village apparatus in terms of managing village finances, especially village funds. The indicators used are based on Naimah (2017) which include; village financial planning, village finance implementation, village financial administration, reporting and accountability. The scale used is an interval scale in the form of a 5-point Likert scale.

c. Utilization of Information Technology $\left(\mathrm{X}_{2}\right)$. Utilization of information technology is the use of technology in the form (hardware, software, useware) which is used to obtain, transmit, process, interpret, store, organize, and use data meaningfully to obtain quality information. The indicators used are based on Sapartiningsih, Suharno and Kristianto (2018) which include; use the application software, the process of computerized accounting , accounting and managerial integrated, employees capable of clicking operate the computer well, Employees can take advantage of the computer in the input data quickly . The scale used is an interval scale in the form of a 5-point Likert scale.

d. Internal Control System $\left(\mathrm{X}_{3}\right)$, the Internal Control System is an integral process for the actions and activities carried out continuously by the leadership and all employees to provide adequate confidence in the achievement of organizational goals through effective and efficient activities, reliability of financial reporting, security state assets, and 


\section{International Journal of Business Management and Economic Review}

Vol. 4, No. 06; 2021

ISSN: 2581-4664

compliance with laws and regulations. The indicators used are based on PP 60/2008 which includes; control environment, risk assessment, control activities, information and communication, and monitoring. The scale used is an interval scale in the form of a 5-point Likert scale.

\section{RESULTS AND DISCUSSIONS \\ Results: \\ Descriptive Analysis}

Descriptive analysis for each variable in this study was obtained based on a questionnaire that had been filled in by the respondents for the variables, namely the accountability of village fund management $(\mathrm{Y})$, understanding of the financial management apparatus $\left(\mathrm{X}_{1}\right)$, the use of information technology $\left(\mathrm{X}_{2}\right)$, the internal control system $\left(\mathrm{X}_{3}\right)$. The following shows the descriptive statistical value of each research variable in Table 1.

Tabel 1 Descriptive statistics

\begin{tabular}{|c|c|c|c|c|}
\hline & $\begin{array}{l}\text { VILLAGE FUND } \\
\text { MANAGEMENT } \\
\text { ACCOUNTABILITY }\end{array}$ & $\begin{array}{l}\text { UNDERSTANDING } \\
\text { OF FINANCIAL } \\
\text { MANAGEMENT } \\
\text { APPLICATIONS }\end{array}$ & $\begin{array}{l}\text { UTILIZATION } \\
\text { OF } \\
\text { INFORMATION } \\
\text { TECHNOLOGY }\end{array}$ & $\begin{array}{l}\text { INTERNAL } \\
\text { CONTROL } \\
\text { SYSTEM }\end{array}$ \\
\hline Mean & 4.57 & 4.70 & 4.42 & 4.52 \\
\hline Std. Deviation & 0.34 & 0.24 & 0.31 & 0.33 \\
\hline Minimum & 3.63 & 3.88 & 3.45 & 3.70 \\
\hline Maximum & 5.00 & 5.00 & 4.80 & 5.00 \\
\hline
\end{tabular}

Based on the results of descriptive statistics, it can be seen that the four research variables, namely the accountability of village fund management (Y), understanding of the financial management apparatus $\left(\mathrm{X}_{1}\right)$, the use of information technology $\left(\mathrm{X}_{2}\right)$, the internal control system $\left(\mathrm{X}_{3}\right)$ show a higher average value. the value of the standard deviation. This indicates that the four research variables have a more stable level of data distribution. It can also be seen from the difference in the value of the minimum and maximum values of the four variables that have the distance (range) is not too far away.

\section{Research Instrument Testing Results}

a. Based on the results of the validity test, it shows that the correlation coefficient obtained from each item of the village fund management accountability variable $(Y)$, understanding of the financial management apparatus $\left(\mathrm{X}_{1}\right)$, the use of information technology $\left(\mathrm{X}_{2}\right)$, the internal control system $\left(\mathrm{X}_{3}\right)$ are all above the critical value of the product moment correlation (correlation coefficient> 0,268) so that the questionnaire used can be declared valid.

b. Based on the p engujian reliability in mind that each instrument in this study reliable (reliably) because the value Cronb ach's Alpha greater than 0,6. So it can be concluded that the questionnaire used as a measurement tool in this study is feasible to use (reliable).

\section{Classical Assumption Testing Results}




\section{International Journal of Business Management and Economic Review}

Vol. 4, No. 06; 2021

ISSN: 2581-4664

Based on the histogram graph, it is known that the observation data is normally distributed where the curve is normal. While the P-Plot graph is known that the points move in the direction of the linear line, so it can be concluded that the research regression model is linear.

Based on the figure tolerance of variable understanding of financial management apparatus $\left(X_{1}\right)$, use of information technology $\left(X_{2}\right)$, and internal control system $\left(X_{3}\right)>0.10$, which means that no multikoline a rity between the independent variables. Meanwhile, the VIF value calculation results also showed that none of the independent variables that have a VIF value of more than 10. Thus, it can be concluded that in this study the regression model did not happen multikoline a rity between the independent variables.

From the graph scatterplot is known that there is no particular pattern in the chart, therefore it can be concluded that the regression model in this study is homoskedastisitas or not happen heteroskedastisitas.

\section{Regression Testing Results}

The results of testing the research regression can be seen in the Table 2 below:

Table 2 Research Regression Testing Results

\begin{tabular}{|l|l|l|l|l|l|}
\hline No. & Variable Name & $\begin{array}{l}\text { Regression } \\
\text { Coefficient } \\
(\beta)\end{array}$ & $\begin{array}{l}\text { t Count } \\
(\mathrm{t} \text { Table) }\end{array}$ & $\begin{array}{l}\text { Significance } \\
\text { (Provisions) }\end{array}$ & Conclusion \\
\hline 1 & $\begin{array}{l}\text { Understanding of } \\
\text { the Financial } \\
\text { Management } \\
\text { Apparatus }\left(\mathrm{X}_{1}\right)\end{array}$ & 0,262 & $\begin{array}{l}2,493 \\
(2,010)\end{array}$ & $\begin{array}{l}0,042 \\
(0,05)\end{array}$ & Take effect \\
\hline 2 & $\begin{array}{l}\text { Utilization of } \\
\text { Information } \\
\text { Technology }\left(\mathrm{X}_{2}\right)\end{array}$ & 0,130 & $\begin{array}{l}2,896 \\
(2,010)\end{array}$ & $0,037(0,05)$ & Take effect \\
\hline 3 & $\begin{array}{l}\text { Internal Control } \\
\text { System }\left(\mathrm{X}_{3}\right)\end{array}$ & 0,561 & $\begin{array}{l}3,867 \\
(2,010)\end{array}$ & $0,000(0,05)$ & Take effect \\
\hline 4 & \multicolumn{2}{|l|}{$\mathrm{F}$ value $=27.594 ; \mathrm{Sig} . \mathrm{F}=0,000$} \\
\hline 5 & \multicolumn{2}{|l|}{$\mathrm{R}$ value $=0.796 ; \mathrm{R}{ }^{2}=0.633 ; \mathrm{Adj} . \mathrm{R}^{2}=0.610$} \\
\hline
\end{tabular}

Based on the results of the regression tests, the multiple linear regression equation is obtained as follows:

$\mathrm{AVFM}=0,230 \mathrm{Constant}+0,262 \mathrm{PAPK}+0,130 \mathrm{PTI}+0,561 \mathrm{SPI}+\varepsilon$

\section{Discussions}

The Effect of the Understanding of the Financial Management Apparatus on the Accountability of Village Fund Management

The results showed that the understanding of the financial management apparatus influenced the accountability of village fund management in Aceh Sin gkil district. The results of this study are in accordance with the theory expressed by Conner and Prahalad (1996) which states that understanding is an important resource for every individual in an organization because 


\section{International Journal of Business Management and Economic Review}

Vol. 4, No. 06; 2021

ISSN: 2581-4664

understanding plays an important role so that an organization can run optimally. The understanding that financial management officers at village officials need to have is related to regulations governing village fund management such as Permendagri No. 113/2014 concerning Village Financial Management and Permendes No. 21 of 2016 concerning Determination of Priority for the Use of Village Funds. It is hoped that the financial management apparatus' understanding of these regulations can create accountability for village fund management.

Based on the results of obtaining the questionnaire, it is known that on average the respondents agree that financial managers, especially village heads and village treasurers, are obliged to be accountable for village funds in the form of reporting, this will require the village head and village treasurer to have an understanding of the accountability of village funds. Then, on average, respondents also agreed that financial managers must have a good understanding of village fund management, this is important for realizing accountability for village fund management in each village in Aceh Singkil District.

The results of this study are in accordance with the results of research conducted by Suherwan and Kamaliah (2017), the results of his research found that human resources as financial managers must have a good level of understanding to realize the successful implementation of village fund allocation. In addition, the results of this study are also consistent with the results of research conducted by Yesinia, Yuliarti, and Puspitasari (2018), Indrianasari (2017) and Hasniati (2016) which state that officials who have an understanding of village fund management will play a role in realizing management accountability. village funds.

\section{Effect of Information Technology Utilization on Village Fund Management Accountability}

The results showed that the use of information technology had an effect on the accountability of village fund management in Aceh Singkil District. The results of this study are in line with the explanations put forward by Sapartiningsih, Suharno and Kristianto (2018) who state that the use of information technology in the form of computers helps village officials in managing village documents as a whole. This computer is used as a work aid in the process of preparing village government financial reports. So that village officials are able to input data faster than using the manual method. The use of this computer has advantages in the accuracy and accuracy of the results of data operations so that it will reduce errors that occur.

The results of this study also support the theory put forward by Suparman (2014:3) which states that the use of information technology includes data processing, information processing, management systems, electronic work processes and the use of advances in information technology so that public services can be accessed easily and cheaply. by the community.

Based on the results of obtaining the questionnaire, it is known that the average respondent agrees that information technology has been used in the management of village funds even though in reality it has not been fully utilized by the village financial management apparatus. Respondents also agreed that the entire accounting process in managing village funds from the start of transactions to reporting had been computerized. In addition, respondents also agreed that all reports, both financial reports and managerial reports in the management of village funds, must be generated from an integrated information system. This is to increase the accountability of village fund management to the public, especially the community. 


\section{International Journal of Business Management and Economic Review}

Vol. 4, No. 06; 2021

ISSN: 2581-4664

The results of this study are in accordance with the results of research conducted by Sapartiningsih, Suharno and Kristianto (2018), Yudianto and Sugiarti (2018) and Suherwan and Kamaliah (2017) which prove that the use of information technology affects the accountability of village fund management.

\section{The Effect of the Internal Control System on the Accountability of Village Fund Management}

The results showed that the internal control system had an effect on the accountability of village fund management in Aceh Singkil Regency. The results of this study are in accordance with those mandated in PP. 60 of 2008 which confirms that the Internal Control System is a business, action and activity carried out at any time by the leadership and all employees so that organizational goals can be achieved by means of appropriate and easy activities, good financial reporting, security of state assets, and orderly regulations legislation.

This is in accordance with what was stated by the Financial and Development Supervisory Agency (BPKP) which stated that the Government Agency Supervisory Apparatus is a means of fostering the implementation of the Government Agency Internal Control System (SPIP). This SPIP then has an important role in overseeing the accountability of village financial management both in terms of assurance and consulting.

The results of this study are in accordance with the results of research conducted by Yesinia, Yuliarti and Puspitasari (2018) which prove that the internal control system has a positive and significant effect on the accountability of the management of village fund allocations in Yosowilangun District, Lumajang Regency. Similar results are expressed by Yudianto and Sugiarti (2018) which show that the internal control system affects the financial management accountability of village funds in the Karawang Regency area of West Java Province. Based on the results of the questionnaire obtained, it is known that the average respondent agrees that SPI must be implemented and carried out by all elements of the government apparatus, especially the financial management apparatus, this is to minimize the level of misappropriation of village funds by certain parties.

The results of this study are also consistent with the results of research by Naimah (2017) which proves that the implementation of SPI in regional financial management will create accountability for village fund management in the Serdang Bedagai Regency Government.

\section{CONCLUSIONS AND SUGGESTIONS Conclusions}

The understanding of the financial management apparatus, the utilization of information technology and the internal control system have a significant influence on the accountability of village fund management in Aceh Singkil District either simultenously and partially

1. To achieve accountability for village fund management, it is necessary to have activities that increase the understanding of financial management apparatus, especially village funds, such as training to increase the capacity of financial managers, technical guidance for village officials for managing finance and other competency training for village officials.

2. The District Government also needs to provide technical training for village financial management officials to be more proficient and professional in managing village finances by utilizing information technology provided by the local government. 


\section{International Journal of Business Management and Economic Review}

Vol. 4, No. 06; 2021

ISSN: 2581-4664

3. To assure the Good Corporate Governance practices, it is required to have an effective supervision by the government internal supervisory apparatus so that the accountability of village funds can be carried out properly without any misappropriation and abuse of power by certain parties.

\section{REFERENCES}

Agus, P. \& W. Madya. (2015). Pengelolaan Keuangan Desa: Sistemdan Prosedur Pertanggungjawaban Keuangan Desa. Artikel Publikasi. Badan Pendidikam dan Pelatihan Keuangan Kementerian Keuangan.

Conner, K. R., \& Prahalad, C. K. (1996). A Resource-Based Theory of The Firm: Knowledge Versus Opportunism. Organization Science, 478-496.

Hadiyati, S. N. (2018). Studi Identifikasi Faktor-Faktor Yang Dapat Mempengaruhi Pengelolaan Keuangan Desa. Jurnal MONEX. 7 (2), 435-442.

Hamzah B. Uno \& Nina Lamatenggo. (2011). Teknologi Komunikasi dan Informasi Pembelajaran, Jakarta: PT Bumi Aksara.

Hasniati. (2016). Model Akuntabilitas Pengelolaan Dana Desa. Jurnal Analisis dan Pelayanan Publik. 2 (1). Universitas Hasanuddin: Makasar.

Indrajit, R. E. (2000). Manajemen Sistem Informasi dan Teknologi Informasi, Pengantar Konsep Dasar.

Indrianasari, N. T. (2017). Peran Perangkat Desa dalam Akuntabilitas Pengelolaan Keuangan Desa. Jurnal Ilmiah Ilmu Akuntansi, Keuangan dan Pajak. 1 (2). STIE Widya Gama: Lumajang.

Jurniadi, D. \& D. B. Paranoan. (2015). Faktor-Faktor Yang Berpengaruh Terhadap Efektivitas Penyaluran Alokasi Dana Desa Di Kecamatan Teluk Pandan Kabupaten Kutai Timur. Artikel online melalui e-journals.unmul.ac.id. Diakses pada 28/09/2019.

Lantip, P. D. \& Riyanto. (2011). Teknologi Informasi Pendidikan Yogyakarta: Gava Media.

Mardiasmo. (20100. Akuntansi Sektor Publik. UII Pres: Yogyakarta.

Naimah. (2017). Faktor-Faktor Yang Mempengaruhi Akuntabilitas Keuangan Desa Pada Pemerintah Kabupaten Serdang Bedagai. Tesis. Magister Akuntansi Fakultas Ekonomi Dan Bisnis Universitas Sumatera Utara Medan.

Peraturan Pemerintah Nomor 60 tahun 2008 tentang Sistem Pengendalian Internal Instansi Pemerintahan.

Peraturan Menteri Dalam Negeri Nomor 113 Tahun 2015 tentang Pengelolaan Keuangan Desa.

Permendes No. 21 Tahun 2016 tentang Penetapan Prioritas Penggunaan Dana Desa.

Pramesti, S. (2015). KPK Temukan 14 Potensi Masalah Pengelolaan Dana Desa. Sindonews.com. Diakses pada 28/09/2019.

Putra, E. (2017). Kurang Transparan, Pengelolaan Dana Desa Jadi Polemik. Artikel online melalui http://www.ajnn.net/news/kurang-transparan-pengelolaan-dana-desa-jadipolemik/index.html. Diakses pada 02/09/2019.

Sapartiningsih, D., Suharno, \& D. Kristianto. (2018). Analisis Pengaruh Kompetensi Sumber Daya Manusia, Pemanfaatan Teknologi Informasi, Partisipasi Penganggaran Dan Pengawasan Terhadap Akuntabilitas Pengelolaan Dana Desa. Jurnal Akuntansi dan Sistem Teknologi Informasi, 14 (1), $100-114$

Schiavo-Campo, S., \& D. Tomasi. (1999). Managing Government Expenditure. Asia Development 


\section{Bank. Manila.}

Stanbury, W. T. (2003). Accountability to Citizens in the Westminster Model of Government: More Myth Than Reality. Canada Fraser Institute Digital Publications.

Suherwan \& Kamaliah. (2017). Analisis Faktor-Faktor Yang Mempengaruhi Keberhasilan Implementasi Alokasi Dana Desa. Jurnal Tepak Manajemen Bisnis. IX (2), 201-214.

Sujarweni, V. Wiratna. (2015). Akuntansi Desa: Panduan Tata Kelola Keuangan Desa. Pustaka Baru: Yogyakarta.

Suparman, W. E. (2014). Pengaruh Kualitas Sumber Daya Manusia dan Pemanfaatan Teknologi Informasi terhadap Keterandalan Pelaporan Keuangan Pemerintah Daerah Kabupaten Buleleng. e-Journal S1 Akuntansi. Universitas Pendidikan Ganesha. 2 (1), 1-10.

Triandis, H. C. (1980). Values, Attitudes, and Interpersonal Behavior. InUniversity of Nebraska. Dept. of Psychology. Nebraska Symposium on Motivation. University of Nebraska Press, 196-259.

Undang-Undang No. 6 Tahun 2014 tentang Desa.

Widodo, J. (2011). Analisis Kebijakan Publik (Konsep dan Aplikasi Proses Kebijakan Publik). Malang: Bayu Media.

Yesinia, N. I., N. C. Yuliarti, dan D. Pusitasari. (2018). Analisis Faktor yang Mempengaruhi Akuntabilitas Pengelolaan Alokasi Dana Desa. Jurnal Aset (Akuntansi Riset), 10 (1), 105112.

Yudianto, I \& E. Sugiarti. (2018). Pengaruh Penerapan Sistem Pengendalian Instansi Pemerintah (SPIP) Terhadap Akuntabilitas Pengelolaan Dana Desa. Artikel Publikasi. Fakultas Ekonomi dan Bisnis. Universitas Padjadjaran. 